\begin{tabular}{|l|} 
A system of statistical measurement \\
of the influence of digital technologies \\
on the efficiency of management has \\
been devised. It is determined that in \\
the process of intensification of digita- \\
lization processes, various methodolog- \\
ical approaches to statistical measure- \\
ment of management efficiency were \\
distinguished. Indices used to compile \\
international ratings for the develop- \\
ment of digital technologies have been \\
established. The existing methodical \\
approaches of statistical measurement \\
of influence of digitalization on efficien- \\
cy of public administration have been \\
analyzed. In this regard, it was deter- \\
mined that there is no unified meth- \\
od of evaluation. A conceptual model \\
of the system of statistical measure- \\
ment of management efficiency under \\
the conditions of digitalization at the \\
organizational level has been built. It \\
is substantiated that the devised model \\
creates the basis for the formation of \\
theoretical and methodological foun- \\
dations for statistical measurement of \\
the impact of digital technologies on \\
management efficiency. Statistical indi- \\
cators of the impact of digital technol- \\
ogies on management efficiency were \\
systematized. The composition of indi- \\
cators of measurement of external eff- \\
ciency, efficiency coefficients of the con- \\
trolled subsystem and control subsystem \\
was clarified. A procedure for calculat- \\
ing the indicator of the overall efficien- \\
cy of management has been devised. \\
A methodical approach for diagnos- \\
ing the movement of management effi- \\
ciency indicators was proposed. It is \\
established that differences in the speed \\
of movement lead to large differenc- \\
es in the values of indicators. It has \\
zeen determined that solving the system \\
cal measurement of the level of digitali- \\
of equations makes it possible to find \\
the intersection points of linear trends. \\
The use of the proposed methodologi- \\
cal approach could make it possible to \\
measure the quantitative and qualita- \\
tive effects of digitalization and ensure \\
effective management at all levels by \\
taking into consideration the interests \\
of all stakeholders \\
\end{tabular}

UDC 311.21

DOI: $10.15587 / 1729-4061.2022 .252911$

\section{DEVELOPMENT OF A SYSTEM FOR STATISTICAL MEASUREMENT OF THE INFLUENCE OF DIGITAL TECHNOLOGIES ON THE EFFICIENCY OF MANAGEMENT}

\section{I gor Dunayev}

Doctor of Science in Public Administration, Professor Department of Economic Policy and Management Educational and Research Institute «Institute of Public Administration» V. N. Karazin Kharkiv National University Svobody sq., 4, Kharkiv, Ukraine, 61022 Director

Research Center of Economic and Legal Solutions in the Area of Application of Distributed Ledger Technologies Otakara Yarosha str., 18 a, Kharkiv, Ukraine, 61045

Iryna Hotlib

Corresponding author $\mathrm{PhD}$, Associate Professor* E-mail: irinagotlib@protonmail.com

Juliya OIvinskaya $\mathrm{PhD}$, Associate Professor, Head of Department* Olena Fomina $\mathrm{PhD}$, Associate Professor**

Diana Hrybova

Doctor of Economic Sciences, Associate Professor Department of Business Consulting and International Tourism Dmytro Motornyi Tavria State Agrotechnological University Bohdan Khmelnytskiy ave., 18, Melitopol, Ukraine, 72312

$\mathrm{Nataliya} \mathrm{Olentsevych}$

$\mathrm{PhD}$, Associate Professor

Department of Management and Marketing Kyiv National Linguistic University Velyka Vasylkivska str., 73, Kyiv, Ukraine, 03150

Yevhen Popov Postgraduate Student** Senior Manager

Technical Department PJSC «AVDIIVKA COKE PLANT» Industrialny ave., 1, Avdiivka, Ukraine, 86066

O leksandr Nosyriev $\mathrm{PhD}$, Associate Professor Department of International Business and Finance National Technical University «Kharkiv Polytechnic Institute» Kyrpychova str., 2, Kharkiv, Ukraine, 61002 *Department of Statistics Odessa National Economic University Preobrazhenskaya str., 8, Odessa, Ukraine, 65082 **Department of Economics, Accounting and Taxation Donetsk National Technical University Shybankova sq., 2, Pokrovsk, Ukraine, 85300

\section{Introduction}

One of the priority tasks on the agenda of modern world trends is the development of the digital economy. On a global scale, digital transformation has covered all levels of the socio-economic areas. At the same time, the success of the implementation of the digitalization strategy in many cases depends on how well the monitoring and evaluation of the effectiveness and effectiveness of digital transformations are executed. As a result, there are growing demands from business representatives, the population, and the state for information provided by official statistics. In this regard, 
there is a development of methods of statistical observation and measurement of the impact of digital technologies on efficiency processes, which requires the introduction of new rules, procedures, instructions. The main response to the challenges associated with the need to deepen existing assessment methods is, first of all, the formation of optimal subsystems of information and methodological support that satisfy the requests of all stakeholders. In most countries, the practice of statistical measurement of the digitalization of the economy is limited to the study of information and communication technologies. In accordance with this, the components of the development of the information industry are measured, in particular, the level of training, information infrastructure, the level of use of information and communication digital technologies at different levels of management [1]. It is advisable to note that there is no officially approved methodology for assessing the impact of digital technologies on any processes of socio-economic development at present. The composition of the available statistical information only partially characterizes the development of the digital economy of countries. Monitoring and evaluation of digital transformation requires the formation of a comprehensive system of performance and efficiency indicators. Moreover, the interests of all users of digital technologies should be taken into consideration - the state, businesses, and citizens [2]. This will assess the effect of the technologies being implemented on all stakeholders, as well as ensure that the necessary balance is struck between accountability for the results achieved and the variability of technological solutions inherent in the modern stage of technology development. Current strategic and program documents are more focused on monitoring and assessing the creation of conditions and demand for certain types of digital interaction. At the same time, the impact of digitalization on management efficiency is still not taken into consideration enough. In this regard, the relevance of the development of a methodology for statistical measurement of the impact of digitalization on the effectiveness of management grows. On the one hand, this will make it possible to process information received from statistical services and other official sources, and, on the other hand, it will create additional opportunities for assessing these indicators in their systemic unity. Thus, research on the development of a system for statistical measurement of the impact of digital technologies on management efficiency is relevant.

\section{Literature review and problem statement}

Accelerating the processes of digital technology implementation at all levels of management requires the formation of a system for statistical measurement of their impact on performance indicators.

Study [3] summarizes understanding of specific aspects of digital transformation but lacks an exhaustive picture of its nature and consequences. At the same time, the author notes that the new digital reality opens up a huge potential for innovation and productivity in organizations and goes beyond the firm to influence individuals, industries, and society. At the same time, it affects the ability of firms to maintain their competitive advantage, which makes it more fragile than ever, which is due to the inability to control numerical factors of the environment. The approaches proposed in the cited work help better understand the strategic consequences of digital transformation and the dynamic interactions that occur between firms and their environment since digital technologies directly affect these interactions. The development of future research in this direction will be useful, for example, in determining the relationships of the organizational system, as well as potential feedback between the use of digital technologies and changes in consumer behavior.

The continuation of the organizational aspect of efficiency is described in work [4], which states that the introduction of digital technologies and concepts of Industrial 4.0 is becoming increasingly important for companies operating in dynamic and competitive markets. In practice, however, these organizations have difficulty implementing these concepts, since Industrial 4.0 is more of a concept than a ready-to-implement solution. In addition, its complexity hinders the successful implementation of Industrial 4.0 systems, which really include all organizational aspects and levels. The cited study presents a structure for evaluating and guiding the implementation of Industrial 4.0, which builds on an understanding of maturity and alignment of capabilities. Based on this, each organization can develop its own "road map" to increase efficiency from the introduction of Industrial 4.0. The logical continuation of that work is [5] where it is noted that in accordance with Industrial 4.0 digital enterprises develop innovative opportunities, which is an important problem for Chinese manufacturers. The authors were among the first to explore the possibilities of information technology, digital transformation, as well as the innovative productivity of production enterprises. Using the survey method, a qualitative comparative analysis and modeling of structural equations was carried out to study the multiple relationships between information and technological capabilities, digital transformation, and innovation efficiency. The reported results indicate the positive impact of information technology capabilities on the effectiveness of the innovation process and digital transformation, as well as the positive impact of digital transformation on both processes. The limitation of this approach is the use of a subjective statistical method, in particular fuzzy sets.

A given problem is solved in [6], which reports an empirical study into the impact of digital transformation on the operational and financial efficiency of Chinese companies. The findings suggest that the intensity of digital transformation has a positive correlation with operational performance and a U-shaped correlation with financial performance, including profit. In addition, it has been found that digital transformation has a longer-lasting impact on operating performance than on financial results. With competent policies and an innovative environment, the improvement of operations through digital transformation is rapid. The cited paper demonstrates the differentiated impact of digital transformation on various dimensions of organizational efficiency and provides recommendations for companies to set the goals of digital transformation. This indicates the practical significance of the study.

Study [7] also tackles problems of researching the mediation effect of performance measurement systems (PMS) in the relationship between digital capabilities and financial indicators. In addition, the cited study looks at how different types of digital capabilities can fuel PMS, leading to improved financial performance. The results show that PMS largely mediates the relationship between digitally connected human capabilities and collaboration opportunities and financial performance. However, no significant mediation 
effect of PMS was found between digital technical and innovation-related capabilities and financial performance.

The purpose of [8] is also to identify the relationship between the financial performance of companies and the degree of digitalization of their business processes. As the main financial indicator, it is proposed to use operating profit, which reflects the results of the current core activities of enterprises. To calculate the digitalization index, McKinsey's information data is taken on the basis of six measurements: digital marketing, experience with digital products, e-commerce, electronic customer relationship management (E-CRM), social networks. For statistical measurement of the impact, the regression analysis method was used, as a result of which it was found that the digitalization index has a positive effect on the operational efficiency of companies. At the same time, the level of influence depends on the industry, maturity, and size of the enterprise. It is concluded that the greatest effect of digitalization is observed among enterprises with traditionally high digital maturity. These are companies from the field of finance, technology, or communications, where digitalization of business is vital and where slowing down the processes of digital transformation is unacceptable. Assessing the impact of digitalization of companies based on their operational activities will allow the management of companies to choose the only correct strategy in matters of digital transformation, which will ensure the competitiveness of the company, increase its financial efficiency, and contribute to its development. The cited study is useful even nationwide because it makes it possible to choose industries that should be supported by subsidization. Similarly to the previous study, work [9] reports an assessment of the impact of digitalization on the financial results of the company. Another approach to measuring the impact of digital technologies is considered in [10]. The cited paper assesses the relationship between digital mergers and acquisitions, the digital knowledge base on the part of the buyer, and the implications for digital innovation and the effectiveness of the firm. Statistical regression analysis is used for evaluation.

Numerous studies addressed measuring the impact of digital technologies on supply chains. Paper [11] examines the impact of digitalization and Industry 4.0 on analysis of the ripple effect and disruption risk control in the supply chain (SC). The structure of the study combines results from two isolated areas, that is, the impact of digitalization on SC management (SCM) and the impact of SCM on ripple effect control. Studies [12-14] substantiate the role of artificial intelligence in building supply chain sustainability. The results reported in [12] are useful for individuals who make integrated decisions in deploying artificial intelligence to create a sustainable supply chain. In [13], studies are conducted on various definitions and classifications of supply chain risk and related concepts, such as uncertainty. The aim of the cited work was a comprehensive supply chain study that addresses problems related to supply chain risk management using approaches to the AI spectrum. With the development and evolution of information technology, competition is becoming increasingly intense on a global scale. Many companies predict that the future of supply chain management (SCM) could change dramatically, from planning, optimization to transportation with the presence of artificial intelligence. People will increasingly be interested in machine learning, artificial intelligence, and other intelligent technologies from the point of view of SCM. In this context, study [14] provides an overview of the concept of artificial intelligence and SCM.
The current state of digital technologies in the business of countries with a transformational economy is radically different from the modern world one. In this regard, international methodologies for determining the level of digital maturity of business using appropriate indicators due to the low overall use of digital technologies in the economic space are unacceptable. Therefore, the task of developing a national methodology for determining the digital maturity index of business is relevant. Such a methodology should take into consideration the current state of the national economy, reflect an in-depth analysis of digital indicators of the maturity of business structures. In addition, it should take into consideration their dynamics, be flexible in order to respond quickly to new economic processes and phenomena, and ensure further unification with international methodologies (for example, DESI). Article [15] analyzes international approaches to measuring the digital maturity of business structures and proposes a methodology adapted to unstable economic conditions for determining the digital maturity index of business.

Paper [16] explores the role of digital technologies in transforming the service business. The authors look at digital technologies such as the Internet of Things (IoT), cloud computing (CC), and predictive analytics (PA), and their impact on the transformation of services in industrial companies. The Data-Information-Knowledge-Wisdom (DIKW) model substantiates how digital technologies transform low-level entities such as data into information and knowledge to support the transformation of manufacturers' services.

Digital technologies are transforming operations, products, and services in large and small organizations. The digital transformation of organizations is represented as a solution to organizational problems related to both efficiency and effectiveness. The process of successful implementation of digital transformation is hampered by various barriers. Article [17] addresses some of the common dilemmas faced by managers that may be relevant in different organizational scenarios. The factors that provide the starting point for creating successful digital transformations in business are analyzed.

Like the previous one, study [18] focuses on the fact that digitalization destroys traditional business models of companies. To this end, in order to maintain the current level of competitiveness, companies need to adapt to changing conditions, develop and implement strategies for introducing digital technologies into their business processes. The cited article presents a structured approach to system modeling of business digitalization.

Work [19] develops a model of digitalization of the state corporate sector, which contains the relationships between factors and indicators of the effectiveness of business process management.

The results of our in-depth review [3-19] prove that the lion's share of scientific research considers the impact of digitalization and the development of digital technologies on operational and financial activities. At the same time, statistical methods of evaluation are used to measure the impact. However, none of copy pasted works contains attempts to form a system of statistical measurement of the impact of digitalization on the effectiveness of management as a whole. In this regard, the development of a system for statistical measurement of the impact of digital technologies on the effectiveness of management is relevant and requires in-depth research. 


\section{The aim and objectives of the study}

The purpose of this study is to develop a system for statistical measurement of the impact of digital technologies on management efficiency. This will create the basis for determining the main drivers of management efficiency at different levels in the context of the digitalization of the economy.

To accomplish the aim, the following tasks have been set:

- to analyze existing methodological approaches to statistical measurement of the level of development of digital technologies;

- to substantiate the conceptual model of the system of statistical measurement of management efficiency under the conditions of digitalization;

- to determine the system of statistical indicators of the conditions for the introduction of digital technologies that have the most significant impact on management efficiency;

- to investigate methods of statistical diagnostics of the movement of control efficiency indicators under the influence of digitalization.

\section{The study materials and methods}

The theoretical and methodological basis of this study was the basic provisions from the theory of efficiency, the concept of digitalization of the economy, theoretical and methodological developments of modern scientists in the management field, as well as individual studies by individual scientists.

In the process of research, a set of scientific methods of cognition was used. To analyze the methodical approaches of statistical measurement of the level of development of digital technologies, the method of generalization, the comparison method, were used. In the process of substantiation of the conceptual model of the system of statistical measurement of management efficiency under the conditions of digitalization, the method of system analysis, algorithmization, and structuring is used. In order to define the system of statistical indicators of the conditions for the introduction of digital technologies that have the most significant impact on the efficiency of management, the method of grouping and formalization is used. The study of the movement of control efficiency indicators under the influence of digitalization was carried out using the statistical method of regression analysis. The coefficients of the regression equation were determined by the method of the least squares.

\section{Results of studying the theoretical and methodological aspects of statistical measurement of the impact of digital technologies on the effectiveness of management}

5. 1. Analysis of methodological approaches to statistical measurement of the level of development of digital technologies

As a result of the strengthening of digitalization processes at different levels of management, a set of methodological approaches to statistical measurement of the level of development of digital technologies at both the micro and macro levels was formed.

At the international level, methods of rating assessment of the digitalization of the economy are actively used. In particular, the following indices are calculated:
- index of development of information and communication technologies (IDI);

- Digital Economy and Society Index (DESI);

- World Digital Competitiveness Index (WDCI);

- Digital Evolution Index (DEI);

- Boston Consulting Group's Digitalization Index (e-Intensity);

- Network Readiness Index (NRI)

- e-government development index (EGDI);

- Electronic Participation Index (EPART);

- Global Connectivity Index (GCI);

- Global Innovation Index (GII) [20].

Each of the indices consists of sub-indexes, according to which a global system of statistical measurement of the level of development of digital technologies is formed. In Ukraine, the monitoring processes of most indices are also taking place. For example, since 2013, it has been participating in the ratings according to the DESI index, that is, since the creation of the national system of indicators of the Information Society [21]. In addition, the intensification of European integration processes leads to an intensification of the development of the digital economy. Thus, according to the EGDI index in 2020, Ukraine ranked $69^{\text {th }}$ out of 193 countries, which characterizes it as a country with a high level of e-government development. According to the NRI index in 2019, Ukraine ranked $67^{\text {th }}$ among 121 countries of the world, and according to the WDCR index $-60^{\text {th }}$ place out of 63 [22].

It is advisable to note that based on the generalization of global digitalization indices, you can calculate an integrated index. The basis for calculating global statistical indices for the development of digital technologies is an approach to monitoring the digital industry at the national level. To this end, a system of statistical indicators measuring the development of the ICT sector is calculated, as well as indicators of the development of the content and media sector [23].

Also of interest are approaches to measuring the effects of digitalization in the field of public administration. In accordance with this, methods of statistical measurement of their mutual influences, which are based on different indicators, were distinguished. However, not all approaches take into consideration the risks from the introduction of digital technologies. The development of proposals for solving this problem created the basis for the creation of a system of indicators of the effectiveness and efficiency of digitalization of public administration. Within the framework of the methodical approach, a variety of indicators of statistical measurement of digitalization in four blocks was grouped. These blocks reflect the assessment of the effectiveness and efficiency of the impact of digital technologies in relation to the following interested groups: the population, business, the state and government officials [24]. Unlike the previous one, there is a method of statistical measurement of digitalization of public administration, which systematizes indicators in the target areas of analysis. In this regard, the first group of indicators belongs to the assessment of the technological implementation of digital solutions for the public administration system. The second group assesses infrastructure readiness for digitalization. The third is the economic feasibility of introducing digital technologies into the public administration sector. In addition, another group of indicators that are used to assess subjective parameters of digitalization (for example, the adoption of digitalization by the population, the consequences of digitalization, digital skills, etc.) is distinguished [25]. 
Statistical measurement of the impact of digital technologies on the activities of organizations involves the use of single indicators and their comparison according to the regional or product principle. Thus, statistical indicators can include the intensity of the use of broadband Internet access among organizations, as well as indicators of e-commerce. Also gaining popularity is the calculation of statistical coefficients, with the help of which it is possible to determine the differences in certain indicators. To do this, the standard deviation, the coefficient of variation, the oscillation coefficient, the Gini coefficient, etc. can be calculated [26].

5. 2. Studying the components of the system of statistical measurement of management efficiency in digitalization

Based on the considered methodological approaches to statistical measurement of the level of development of digital technologies, a conceptual model of the system of statistical measurement of management efficiency under the conditions of digitalization at the organizational level was devised (Fig. 1).

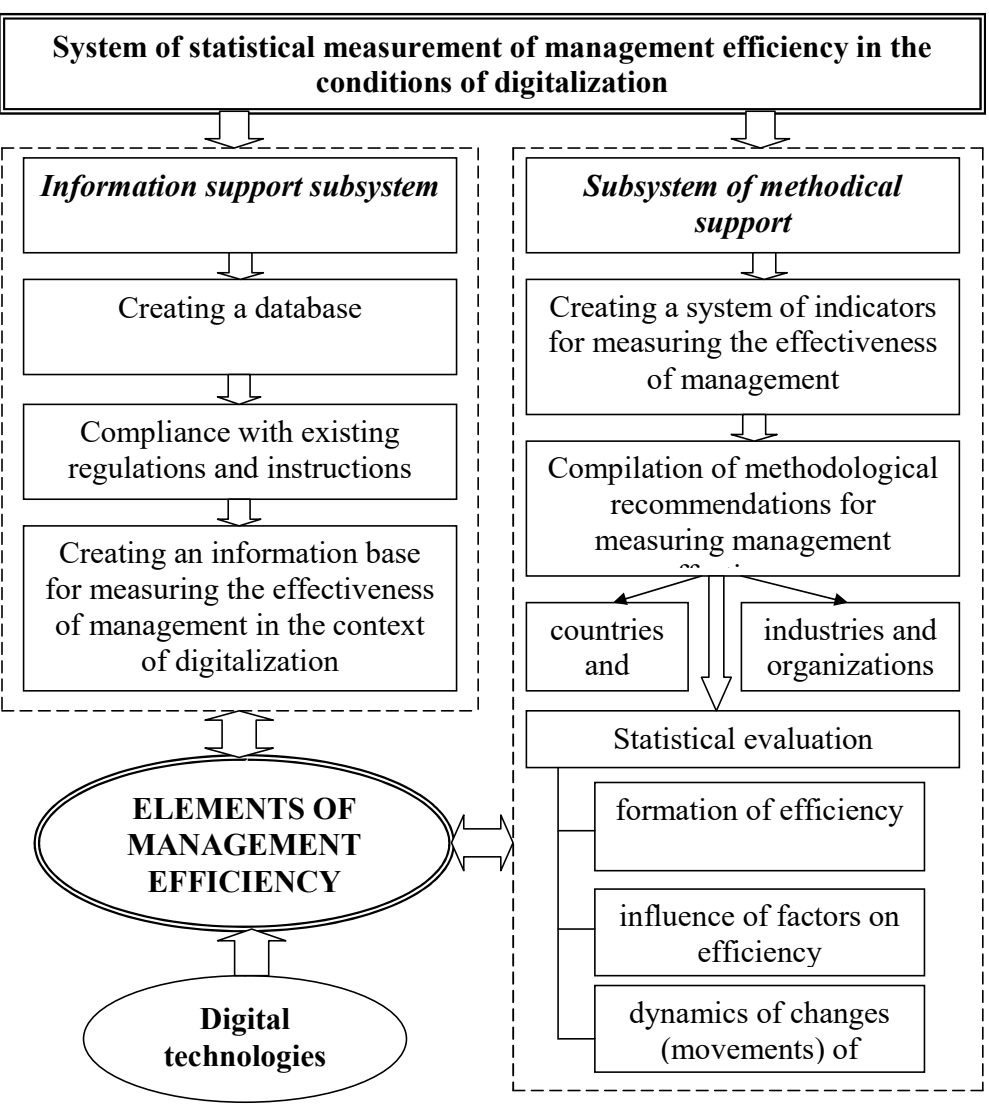

Fig. 1. Conceptual model of the system of statistical measurement of management efficiency in digitalization

Note: complied using data from [27-30]

The constructed conceptual model is a kind of basis for the formation of theoretical and methodological foundations for statistical measurement of the impact of digital technologies on the efficiency of management. In turn, the elements of control efficiency include external efficiency, efficiency of the control subsystem, and the efficiency of the controlled subsystem. Each element is characterized by a specific set of indicators.

Within the framework of the conceptual model, subsystems of information and methodological support are formed, recommendations for analyzing the effectiveness of management are developed. This makes it possible to distinguish the system of statistical indicators of the impact of digital technologies on the efficiency of management and to determine the priority directions for the development of economic entities in the context of digitalization.

5. 3. Results of studying statistical indicators of the impact of digital technologies on management efficiency

According to the theory of general statistics, all indicators that measure a particular phenomenon or process are divided into absolute and relative indicators. In turn, with the help of these indicators, an appropriate system of statistical measurement is formed. The system of statistical indicators of the impact of digital technologies on the efficiency of management is shown in Fig. 2. It is worth noting that the effectiveness of management is considered from the point of view of an integration combination of aspects of system and process approaches. The systematic approach involves the integrity of the controls and their interaction towards achieving the planned results, taking into consideration external factors. The process approach consists in the consistent implementation of the main functions of management. In accordance with this, management efficiency indicators should be divided into indicators of the effectiveness of the management system and indicators of the effectiveness of the management process.

Next, we shall describe in detail the indicators of the effectiveness of the system and the management process.

Since the control system consists of an object of control and a control subject, interacts with the external environment, the key indicators are the efficiency factor of the control and controlled subsystems, as well as the external efficiency factor.

Indicators of external efficiency determine the degree of interaction between the organization, on the one hand, and stakeholders on the other. The latter are usually investors, suppliers, consumers, competitors, state institutions. Since indicators of external efficiency express the balance of interests, they do not have a quantitative assessment.

The efficiency factor of the control subsystem can be determined using an additive model, which includes the effectiveness of management personnel, organizational structure, management technologies, corporate culture.

The efficiency factor of the managed subsystem consists of indicators of the effectiveness of operational financial, marketing, personnel, investment, innovation subsystems [31].

In turn, the management process involves the implementation of the main functions of management. In this regard, the performance indicators of the management process reflect the effectiveness of planning, organization, motivation, control, and coordination. The main criterion of planning is to increase the accuracy and balance of forecasts. Rational organization involves the optimization of the organizational structure. The consequence of effective motivation is an increase in labor productivity. 
Effective control increases the efficiency of management decision-making. ficient, which characterizes the level of development of digital technologies, for a certain indicator of management efficiency.

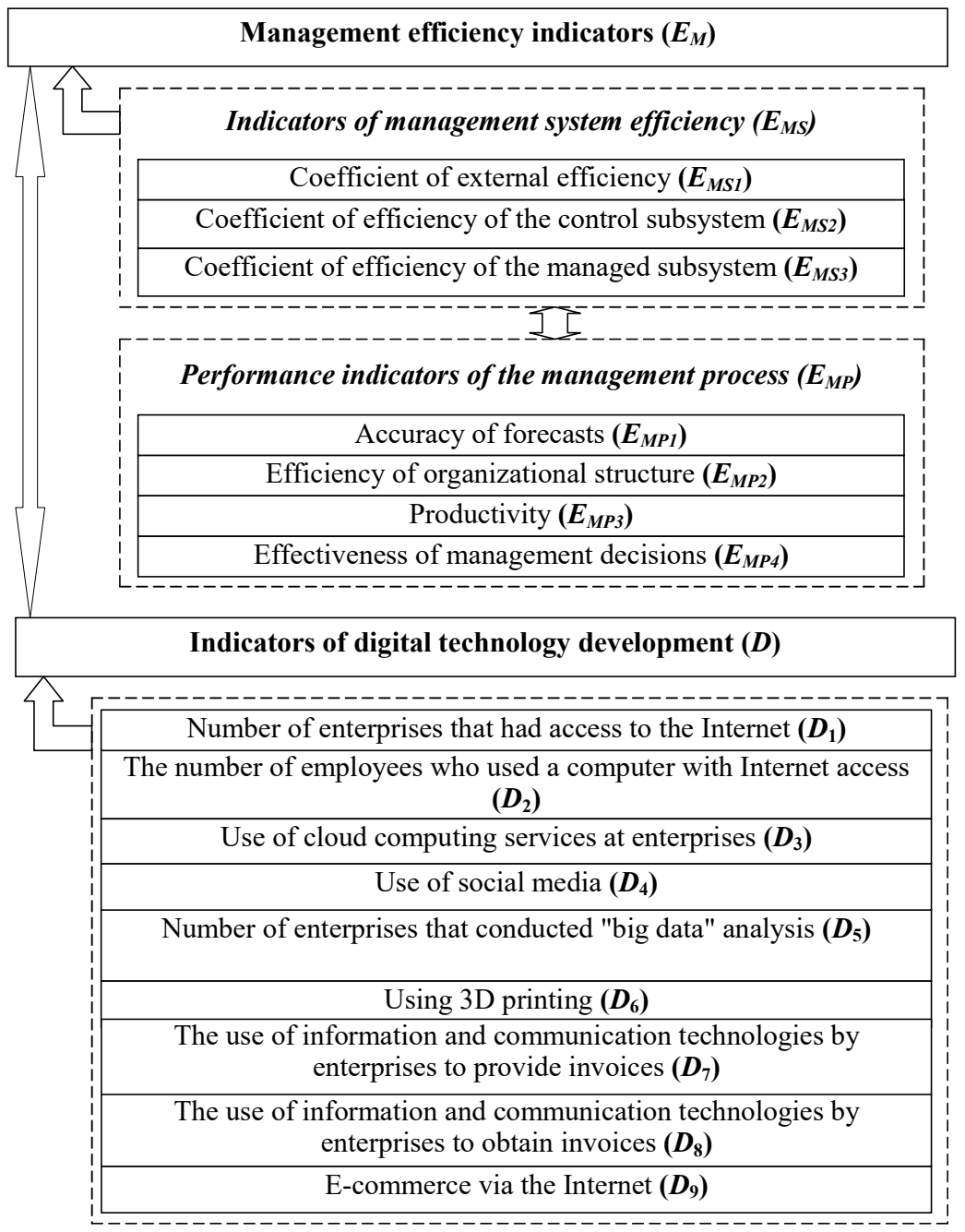

Fig. 2. System of statistical indicators of the impact of digital technologies on management efficiency

Note: complied using data from [29, 32-36]

Also interesting is the approach, which is based on determining the effectiveness of management by comparing the results (profit, profitability, image, market share) with administrative costs. In this case, the total management efficiency factor $(E)$ is calculated, which is as follows:

$$
E=P / A B
$$

where $P$ is the results of the organization's activities;

$A B$-administrative expenses [29].

Indicators characterizing the development of digital technologies are systematized in accordance with the data generated in the State Statistics Service.

The relationship between digitalization processes and management efficiency can be represented as follows:

$$
D \rightarrow E_{M P} \leftrightarrow E_{M S} .
$$

It is worth noting that the strength of the relationship of each indicator can be determined using the correlation coef-
5. 4. Studying the methods of statistical diagnostics of movement of control efficiency indicators under the influence of digitalization

To determine the direction and speed of movement of individual indicators of control efficiency under the influence of digitalization, it is proposed to use the regression equation [37]. According to this, the initial value of the $i$-th control efficiency indicator $\left(E_{i}(t)\right)$ takes the following form:

$$
E_{i}(t)=a_{i}+b_{i} t
$$

where $t$ is the period (years);

$a_{i}, b_{i}$ - parameters of the regression equation.

It is advisable to note that trends in changes in management efficiency indicators under the influence of digitalization have significant differences in different countries, regions, industries, as well as organizations. In the process of statistical diagnostics of the speed of movement of individual indicators of management efficiency under the influence of digitalization, it is possible to compare their level of achievement by some subjects of the economy with respect to others. From a formal point of view, all subjects of the economy experience the consequences of the influence of digital technologies, as a result of which dynamic changes occur in performance indicators. However, these changes are not the same. With the help of a linear regression equation, it is possible to represent an analytical expression of the direction of straight-line motion according to a specific efficiency indicator. It is worth noting that, in this case, the $a_{i}$ coefficient refers to the basic conditions of the $i$-th efficiency indicator, and the $b_{i}$ coefficient is the speed of movement of the subject of the economy under the influence of digitalization according to the $i$-th efficiency indicator.

Given the dynamic changes in indicators, it is advisable to note that different economic entities had different levels of the $i$-th efficiency indicator even before the introduction of digital technologies. At the same time, differences in the speed of movement lead to even greater discrepancies in the values of indicators. At the same time, with the help of solving the system of equations, it is possible to find the intersection points of linear trends. The system of equations is as follows:

$$
\left\{\begin{array}{l}
E_{i}^{n}(t)=a_{i}^{n}+b_{i}^{n} t, \\
E_{i}^{m}(t)=a_{i}^{m}+b_{i}^{m} t,
\end{array}\right.
$$

where $E_{i}^{n}(t), E_{i}^{m}(t)$ is the $i$-th indicator of the effectiveness of management of the $n$-th and $m$-th subject of the economy, respectively. 
By solving the system of equations (4), we find a period $(t)$ when the comparable subjects of the economy have the same level of the $i$-th indicator of management efficiency. The greater the value obtained, the deeper the differences in the impact of digital technologies on management efficiency.

To better understand the proposed methodology, it seems expedient to consider an example of studying the movement of the overall management efficiency indicator under the influence of digitalization at the leading Ukrainian coke plants. In particular, PrAT "Avdiivka coke plant" and PrAT "Zaporizhkoks", which are part of Metinvest, were the selected enterprises. The choice is due to the fact that the company actively uses the experience of introducing digital technologies at its enterprises. In addition, since 2018, a special IT unit responsible for digitalization processes has been set up - Metinvest Digital. Thanks to the newly created division, Metinvest's digital transformation has covered almost all business processes. The company has implemented a comprehensive digital model, which consists of three areas - Business Engagement, Solution Delivery, and Service Management. Business Engagement provides effective interaction between the company's enterprises. Solution Delivery introduces digital innovations. Service Management supports and the introduction of digital technologies and solutions.

The effect of digitalization at Metinvest is comprehensive. Improving the efficiency of the main functions of management and improving the management system affected the level of sales and product quality, customer service, loss reduction. According to the results for 2019, the company saved almost USD 50 million per year. First of all, this is due to the optimization of planning and control functions. Thus, mathematical modeling of the optimal composition of coal seam for coke led to a decrease in the cost of coal charge by $1.1 \%$, as a result of which the savings amounted to USD 20 million. In turn, the use of artificial intelligence to control the temperature in blast furnaces led to a decrease in the silicon content in cast iron from $0.65 \%$ to $0.50 \%$, resulting in a saving of USD $30 \mathrm{mil}-$ lion[38].

At the same time, the intensity of digitalization of management processes at each enterprise differs significantly. The results of calculating the coefficients of regression of the management efficiency indicator for the enterprises studied are shown in Fig. 3 and given in Table 1.

Our analysis of Fig. 3 and Table 1 proves the same trends in the movement of linear trends in the efficiency of management of the studied enterprises. The intersection of trend lines took place in the past (2018) when management efficiency indicators were of the greatest importance. In the future, under unchanged conditions, the trend lines would not cross. The reliability of the forecast is high, as evidenced by the calculated coefficient of approximation.
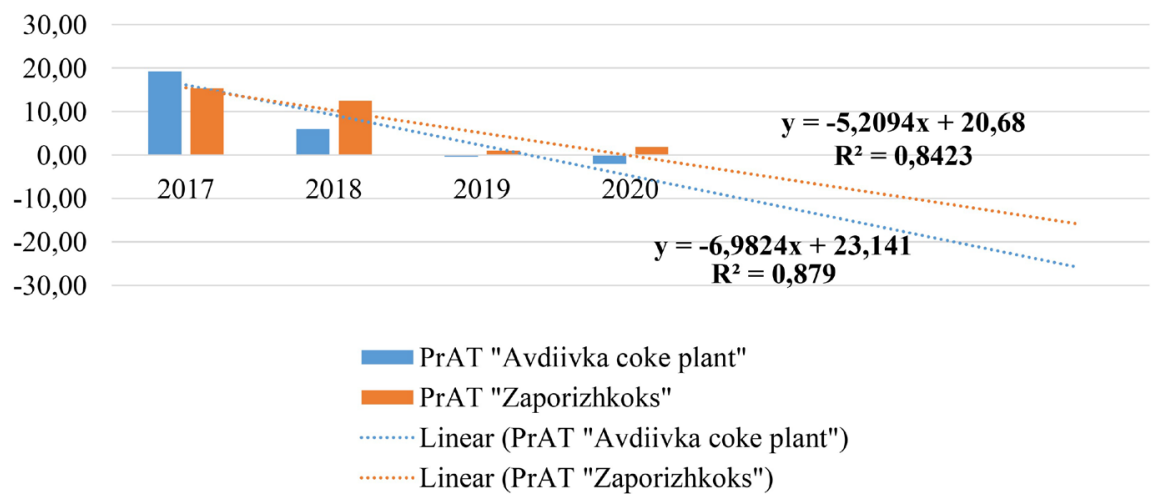

........ Linear (PrAT "Zaporizhkoks")

of coke-chemical enterprises
of in management efficie

Table 1

Parameters of linear trends in management efficiency on the example

\begin{tabular}{c|c|c|c|c|c|}
\multirow{2}{*}{$\begin{array}{c}\text { Enter- } \\
\text { prise }\end{array}$} & \multicolumn{2}{|c|}{$\begin{array}{c}\text { Regression equa- } \\
\text { tion coefficient }\end{array}$} & \multirow{2}{*}{$\begin{array}{c}\text { Approx- } \\
\text { imation }\end{array}$} & \multicolumn{2}{|c|}{$\begin{array}{c}\text { Intersection period with linear } \\
\text { trends, years }\end{array}$} \\
\cline { 5 - 6 } & $a_{i}$ & $b_{i}$ & error, $R^{2}$ & $\begin{array}{c}\text { PrAT “Avdiivka } \\
\text { coke plant" }\end{array}$ & $\begin{array}{c}\text { PrAT “Zapor- } \\
\text { izhkoks" }\end{array}$ \\
\hline $\begin{array}{c}\text { PrAT } \\
\text { Avdiivka } \\
\text { coke } \\
\text { plant" }\end{array}$ & 23.141 & -6.9824 & 0.879 & - & 1.4 \\
\hline $\begin{array}{c}\text { PrAT } \\
\text { Zaporiz- } \\
\text { hkoks" }\end{array}$ & 20.68 & -5.2094 & 0.8423 & 1.4 & - \\
\hline
\end{tabular}

Fig. 3. Determining coefficients for the equations of movement of enterprises under the influence of digitalization

[29, $39-41]$

It is worth noting that the proposed method is universal and can be used to compare the speed of movement and other indicators.

\section{Discussion of results of studying the theoretical and methodological aspects of statistical measurement of the impact of digital technologies on the effectiveness of management}

The analysis of methodological approaches to statistical measurement of the level of development of digital technologies showed the absence of a unified approach. At the same time, experts $[19,42]$ compile various ratings of digitalization of the economy of different levels - international, state, regional, sectoral. The basis of each methodical approach contains a holistic system of sub-indexes, based on which the integrated indicator of the development of digital technologies is calculated, as well as directions and steps for further digitalization are determined [19]. However, the specific variety of methodological approaches at the level of organizations requires their systematic generalization and the choice of the most acceptable option for specific conditions of economic activity.

In the course of our study, we managed to build a conceptual model of the system of statistical measurement of management efficiency under the conditions of digitalization at the organizational level (Fig. 1). Unlike previous studies, which single out only the main elements of the system, the 
proposed model contains security subsystems - informational and methodological, on which the state of functioning of control efficiency elements largely depends. In turn, the elements of control efficiency should include external efficiency, efficiency of the control subsystem, and efficiency of the controlled subsystem.

Based on the conducted studies, the indicators are summarized into a system of statistical indicators of the impact of digital technologies on the effectiveness of management (Fig. 2). The content of each component is substantiated. In addition, it is proposed to establish the relationship, as well as differences between indicators of digital development and management efficiency through the use of statistical coefficients, in particular the correlation coefficient, variation, oscillation.

In order to carry out statistical diagnostics of the movement of control efficiency indicators under the influence of digitalization, it is proposed to use regression analysis. The use of the regression equation will allow for analytical expression of the directions of straight movements according to specific indicators of management efficiency. For statistical comparison of the values of specific indicators, it is proposed to use a system of equations (3). The results of the practical implementation of the recommended methodical approach are shown in Fig. 3 and in Table 1, according to which the same trends in the movement of linear trends in the indicator of management efficiency of the enterprises under study.

The results of our study on the development of a system for statistical measurement of the impact of digital technologies on the efficiency of management will form the basis for ensuring quality management at all levels. At the same time, it acts as a prerequisite for achieving positive effects from the introduction of digital technologies and harmonizing the interests of all stakeholders.

The practical significance of the study is proved by the proposed system of statistical indicators of the impact of digital technologies on the effectiveness of management. In addition, there is an interesting methodological approach to statistically diagnosing the movement of control efficiency indicators under the influence of digitalization, which is universal and can be adapted to measure the speed of movement and other indicators.

Assessing the relevance of the recommended methodical approaches, it is advisable to note that they are universal. In other words, these methods of statistical measurement can be used at different levels of management and for different subjects of economy. As a result, this indicates a certain limitedness of the proposed recommendations due to their generalized content, which does not take into consideration the specificity of development, for example, industry trends.

The development of further research started here is advisable to direct to a deeper and more detailed development of a system of indicators of statistical measurement of the impact of digital technologies on the effectiveness of management of a particular subject of the economy. Particular attention should be paid to the study of relevant digital trends in the basic sectors of the national economy and the assessment of their impact on the components of management efficiency. In turn, this requires expanding the proposed system of statistical indicators of the impact of digital technologies on management efficiency.

\section{Conclusions}

1. It was established that the processes of statistical measurement of the impact of digital technologies on the efficiency of management led to the formation of a set of methodological approaches at both the micro and macro levels. The methods of rating assessment of digitalization of the economy are characterized, the basis for which are global indices for the development of digital technologies. In this regard, the position of Ukraine on the indices EGDI, NRI, WDCR is determined. Approaches to measuring the effects of digitalization in the field of public administration have been determined. It is substantiated that statistical measurement of the impact of digital technologies on the activities of organizations involves the use of single indicators and their comparison according to the regional or product principle.

2. A conceptual model of the system of statistical measurement of management efficiency under the conditions of digitalization at the organizational level is proposed. It is established that this model is a kind of basis for the formation of theoretical and methodological foundations for statistical measurement of the impact of digital technologies on the efficiency of management. The subsystems of information and methodological support and the composition of control efficiency elements, which include external efficiency, efficiency of the control subsystem and efficiency of the managed subsystem, are substantiated.

3. A system of statistical indicators of the impact of digital technologies on the efficiency of management has been developed. Management efficiency indicators are characterized. The indicators of measurement of external efficiency, components of efficiency coefficients of the controlled subsystem and control subsystem are established. The importance of the approach to statistical measurement of the impact of digital technologies, which is based on determining the overall efficiency of management by comparing results with administrative costs, has been proved.

4. Based on the results of the developed system of statistical indicators of the impact of digital technologies on the effectiveness of management, a methodical approach for diagnosing the movement of performance indicators is proposed. Using the linear regression equation, an analytical expression of the direction of rectilinear motion is presented according to a specific efficiency indicator. It is established that differences in the speed of movement cause large differences in the values of indicators. It is determined that with the help of solving the system of equations it is possible to find the intersection points of linear trends. The study of the movement of the general indicator of management efficiency under the influence of digitalization on the example of leading Ukrainian coke plants is considered.

\section{References}

1. Vishnevskiy, K. O., Gokhberg, L. M. et. al. (2019). Chto takoe tsifrovaya ekonomika? Trendy, kompetentsii, izmerenie. Moscow: Izdatel'skiy dom Vysshey shkoly ekonomiki, 82. Available at: https://www.hse.ru/data/2019/04/12/1178004671/2\%20\%D0\%A6 \%D0\%B8\%D1\%84\%D1\%80\%D0\%BE\%D0\%B2\%D0\%B0\%D1\%8F_\%D1\%8D\%D0\%BA\%D0\%BE\%D0\%BD\%D0\%BE\%D0\%BC $\%$ D0\%B8\%D0\%BA\%D0\%B0.pdf 
2. Ukraina 2030E - kraina z rozvynutoiu tsyfrovoiu ekonomikoiu. Available at: https://strategy.uifuture.org/kraina-z-rozvinutoyucifrovoyu-ekonomikoyu.html

3. Vial, G. (2019). Understanding digital transformation: A review and a research agenda. The Journal of Strategic Information Systems, 28 (2), 118-144. doi: https://doi.org/10.1016/j.jsis.2019.01.003

4. Issa, A., Hatiboglu, B., Bildstein, A., Bauernhansl, T. (2018). Industrie 4.0 roadmap: Framework for digital transformation based on the concepts of capability maturity and alignment. Procedia CIRP, 72, 973-978. doi: https://doi.org/10.1016/j.procir.2018.03.151

5. Chu, Y., Chi, M., Wang, W., Luo, B. (2019). The Impact of Information Technology Capabilities of Manufacturing Enterprises on Innovation Performance: Evidences from SEM and fsQCA. Sustainability, 11 (21), 5946. doi: https://doi.org/10.3390/su11215946

6. Guo, L., Xu, L. (2021). The Effects of Digital Transformation on Firm Performance: Evidence from China's Manufacturing Sector. Sustainability, 13 (22), 12844. doi: https://doi.org/10.3390/su132212844

7. Nasiri, M., Ukko, J., Saunila, M., Rantala, T., Rantanen, H. (2020). Digital-related capabilities and financial performance: the mediating effect of performance measurement systems. Technology analysis \& strategic management, 32 (12), 1393-1406. doi: https://doi.org/10.1080/09537325.2020.1772966

8. Cherkasova, V. A., Slepushenko, G. A. (2021). The Impact of Digitalization on the Financial Performance of Russian Companies. Finance: Theory and Practice, 25 (2), 128-142. doi: https://doi.org/10.26794/2587-5671-2021-25-2-128-142

9. Abou-foul, M., Ruiz-Alba, J. L., Soares, A. (2020). The impact of digitalization and servitization on the financial performance of a firm: an empirical analysis. Production Planning \& Control, 32 (12), 975-989. doi: https://doi.org/10.1080/ 09537287.2020.1780508

10. Hanelt, A., Firk, S., Hildebrandt, B., Kolbe, L. M. (2020). Digital M\&A, digital innovation, and firm performance: an empirical investigation. European Journal of Information Systems, 30 (1), 3-26. doi: https://doi.org/10.1080/0960085x.2020.1747365

11. Ivanov, D., Dolgui, A., Sokolov, B. (2018). The impact of digital technology and Industry 4.0 on the ripple effect and supply chain risk analytics. International Journal of Production Research, 57 (3), 829-846. doi: https://doi.org/10.1080/00207543.2018.1488086

12. Belhadi, A., Kamble, S., Fosso Wamba, S., Queiroz, M. M. (2021). Building supply-chain resilience: an artificial intelligence-based technique and decision-making framework. International Journal of Production Research. doi: https://doi.org/10.1080/00207543.2021. 1950935

13. Baryannis, G., Validi, S., Dani, S., Antoniou, G. (2018). Supply chain risk management and artificial intelligence: state of the art and future research directions. International Journal of Production Research, 57 (7), 2179-2202. doi: https://doi.org/10.1080/00 207543.2018.1530476

14. Helo, P., Hao, Y. (2021). Artificial intelligence in operations management and supply chain management: an exploratory case study. Production Planning \& Control, 1-18. doi: https://doi.org/10.1080/09537287.2021.1882690

15. Strutynska, I., Dmytrotsa, L., Kozbur, H. (2019). The Main Barriers and Drivers of the Digital Transformation of Ukraine Business Structures. Proceedings of the 15th International Conference on ICT in Education, Research and Industrial Applications. Integration, Harmonization and Knowledge Transfer, 2387, 50-64. Available at: http://ceur-ws.org/Vol-2387/20190050.pdf

16. Ardolino, M., Rapaccini, M., Saccani, N., Gaiardelli, P., Crespi, G., Ruggeri, C. (2017). The role of digital technologies for the service transformation of industrial companies. International Journal of Production Research, 56 (6), 2116-2132. doi: https:// doi.org/10.1080/00207543.2017.1324224

17. Heavin, C., Power, D. J. (2018). Challenges for digital transformation - towards a conceptual decision support guide for managers. Journal of Decision Systems, 27 (1), 38-45. doi: https://doi.org/10.1080/12460125.2018.1468697

18. Averina, T., Barkalov, S., Fedorova, I., Poryadina, V. (2021). Impact of digital technologies on the company's business model. E3S Web of Conferences, 244, 10002. doi: https://doi.org/10.1051/e3sconf/202124410002

19. Dunayev, I., Kud, A., Latynin, M., Kosenko, A., Kosenko, V., Kobzev, I. (2021). Improving methods for evaluating the results of digitizing public corporations. Eastern-European Journal of Enterprise Technologies, 6 (13 ((114)), 17-28. doi: https:// doi.org/10.15587/1729-4061.2021.248122

20. Goloventchik, G. G. (2018). Rating Analysis of the Level of Digital Transformation of the Economies of EAEU and EU the Countries. Digital Transformation, 2 (3), 5-18. Available at: https://dt.giac.by/jour/article/view/75/61?locale=ru_RU

21. Yegorov, I. Y., Gryga, V. Y. (2019). Comparative Analysis of the Availability of Digitalization Indicators in Ukraine and Other EU Eastern Partnership Countries. Statistics of Ukraine, 3, 56-62. doi: https://doi.org/10.31767/su.3(86)2019.03.06

22. Yavorskyi, P., Taran, S., Shepotylo, O., Hamaniuk, O. (2020). Intehratsiya Ukrainy u yedynyi tsyfrovyi rynok YeS. Potentsiyni ekonomichni pervahy. Kyiv: HO «Ukraiyinskyi tsentr evropeyskoiyi polityky», 51. Available at: https://eu-ua.kmu.gov.ua/sites/ default/files/inline/files/dig_ukraine_eu_15.12.2020__2.pdf

23. Grytsulenko, S., Zakharchenko, L. (2019). Development of comparative assessment method of digital economy based on the integral index. Technology Audit and Production Reserves, 6 (4 (50)), 33-39. doi: https://doi.org/10.15587/23128372.2019 .188751

24. Dobrolyubova, E. I. (2020). Pokazateli rezul'tativnosti i effektivnosti tsifrovizatsii gosudarstvennogo upravleniya. Moscow, 70. Available at: https://papers.ssrn.com/sol3/papers.cfm?abstract_id=3678028

25. Sidorenko, E. L., Bartsits, I. N., Khisamova, Z. I. (2019). The Efficiency of Digital Public Administration Assessing: Theoretical and Applied Aspects. Public Administration, 2, 93-114. Available at: https://cyberleninka.ru/article/n/effektivnost-tsifrovogogosudarstvennogo-upravleniya-teoreticheskie-i-prikladnye-aspekty 
26. Minashkin, V. G., Prokhorov, P. E. (2018). Statistical analysis of the use of digital technologies in organizations: regional aspect. Statistics and Economics, 15 (5), 51-62. doi: https://doi.org/10.21686/2500-3925-2018-5-51-62

27. Artemieva, I. O. (2020). The System for Statistical Measurement of Digital Economy Parameters: Development Trends. Statistics of Ukraine, 1, 66-74. doi: https://doi.org/10.31767/su.1(88)2020.01.08

28. Oliynyk, D. I. (2021). Shchodo vymiriuvannia protsesiv tsyfrovizatsiyi v konteksti tsilei ekonomichnoho vidnovlennia. Natsionalnyi instytut stratehichnykh doslidzhen. Available at: https://niss.gov.ua/sites/default/files/2021-08/tsyfrovizatsiya1.pdf

29. Nazarchuk, T. V., Kosiuk, O. M. (2016). Menedzhment orhanizatsiy. Kyiv: «Tsentr uchbovoi literatury», 560. Available at: http:// pdf.lib.vntu.edu.ua/books/2017/menedzhment_org.pdf

30. Gölzer, P., Fritzsche, A. (2017). Data-driven operations management: organisational implications of the digital transformation in industrial practice. Production Planning \& Control, 28 (16), 1332-1343. doi: https://doi.org/10.1080/ 09537287.2017.1375148

31. Cooper, C., Bou, J. T., Varley-Campbell, J. (2019). Evaluating the effectiveness, efficiency, cost and value of contacting study authors in a systematic review: a case study and worked example. BMC Medical Research Methodology, 19 (1). doi: https://doi.org/10.1186/s12874019-0685-0

32. Kotarba, M. (2017). Measuring Digitalization - Key Metrics. Foundations of Management, 9 (1), 123-138. doi: https://doi.org/10.1515/ fman-2017-0010

33. Parviainen, P., Kääriäinen, J., Tihinen, M., Teppola, S. (2017). Tackling the digitalization challenge: how to benefit from digitalization in practice. International Journal of Information Systems and Project Management, 5 (1), 63-77. doi: https://doi.org/10.12821/ ijispm050104

34. Semenova, V. G. (2015). The System of Indicators for Evaluating the Effectiveness of Intellectual Property Management at Enterprises. Problemy ekonomiky, 2, 179-185. Available at: https://www.problecon.com/export_pdf/problems-of-economy-20152_0-pages-179_185.pdf

35. Vykorystannia informatsiyno-komunikatsiynykh tekhnolohiy na pidpryiemstvakh. Derzhavna sluzhba statystyky Ukrainy. Available at: http://www.ukrstat.gov.ua/operativ/operativ2018/zv/ikt/arh_ikt_u.html

36. Nychyporenko, K. V., Alieksandrova, M. V. Tsyfrovizatsiya. Available at: https://iie.org.ua/wp-content/uploads/2019/02/ Prezentatsiya_Margarita-szhatyiy.pdf

37. Okara, D. V. (2018). Ekonometriya. Odessa: ODABA, 144. Available at: http://mx.ogasa.org.ua/bitstream/123456789/5155/1/\%D 0\%95\%D0\%BA\%D0\%BE\%D0\%BD\%D0\%BE\%D0\%BC\%D0\%B5\%D1\%82\%D1\%80\%D1\%96\%D1\%8F.pdf

38. Hryhorenko, Yu. (2021). Staleva tsyfra: yak metalurhy y hirnyky rozvyvaiut IT-tekhnolohiyi. Available at: https:/gmk.center/ua/ posts/staleva-cifra-yak-metalurgi-j-girniki-rozvivajut-it-tehnologii/

39. PJSC «AVDIIVKA COKE». Available at: https://akhz.metinvestholding.com/en

40. PrAT «Zaporizhkoks». Available at: https://www.zaporozhcoke.com/

41. Nunkoo, R., Seetanah, B., Jaffur, Z. R. K., Moraghen, P. G. W., Sannassee, R. V. (2019). Tourism and Economic Growth: A Metaregression Analysis. Journal of Travel Research, 59 (3), 404-423. doi: https://doi.org/10.1177/0047287519844833

42. Dunayev, I. (2018). The modernization logics and principles of designing a new generation of regional economic policies: findings for recent Ukraine and Eastern-European countries in transition. Modernization: Progress in Economics Research. Vol. 41. New York: NOVA Publ., 53-90. 